\title{
Cease Agricultural Activity Forever? Underestimating the Importance of Symbolic Capital
}

\author{
Shane Conway ${ }^{1}$, John McDonagh ${ }^{1}$, Maura Farrell ${ }^{1}$, Anne Kinsella ${ }^{2}$
}

${ }^{1}$ Discipline of Geography, National University of Ireland, Galway, University Road, Galway, Ireland

${ }^{2}$ Teagasc Agricultural Economics and Farms Surveys Department, Mellows Campus, Athenry, Co. Galway, Ireland

Corresponding Author Email Address: s.conway9@nuigalway.ie

\section{Citation:}

Conway, S.F., McDonagh, J., Farrell, M. and Kinsella, A.,( 2016). Cease

agricultural activity forever? Underestimating the importance of symbolic capital, Journal of Rural Studies, 44: 164-176.

doi:10.1016/j.jrurstud.2016.01.016

\begin{abstract}
Similar to what is occurring on a global scale, Irish agriculture is populated by an older generation of farmers. Consequently, intergenerational family farm transfer is increasingly viewed as crucial to the survival, continuity and future sustainability of the family farm and agricultural sector. A review of existing research highlights how financial incentives that encourage succession and retirement from farming have stimulated little change in the behavioural intentions and attitudes amongst elderly farmers. Drawing on two previously disparate literatures (transferring the family firm and transferring the family farm) and applying Pierre Bourdieu's concept of symbolic capital as a theoretical framework, this paper sets aside financial enticements and presents an insightful, nuanced analysis of the human factors that influence the process of transferring the family farm from the perspective of the senior generation. This research employs a multi-method triangulation design, consisting of self-administered questionnaires in conjunction with complimentary Problem- Centred Interviews, to acquire data on the complex
\end{abstract}


Conway et al., 2016. Cease Agricultural Activity Forever? Underestimating the Importance of Symbolic Capital, Journal of Rural Studies, 44: 164-176

psychodynamic and sociodynamic emotions involved in the process. The prominent themes to emerge from the empirical data are farmers concerns regarding potential loss of identity, status and control upon transferring management and ownership of the family farm and retiring. Many older farmers appear to prioritise the building and maintenance of their personal accumulation of symbolic capital rather than ceasing agricultural activity. The paper concludes by suggesting that future policies and programmes encouraging family farm transfer must take into account the pervasiveness of symbolic capital and work within this structure to develop effective strategies that addresses the emotional well-being of elderly farmers.

\section{Keywords}

Family Farming, Succession, Retirement, Symbolic Capital, Family Firm, Farm Viability

\section{Highlights}

- There are concerns about the sustainability of an aging farming population.

- Financial incentives encouraging intergernational family farm transfer fail to deal with the emotional issues facing ageing farmers.

- Transferring management and ownership of the farm and retiring returns little symbolic capital to older farmers.

- Farmers opt to maintain the facade of normal day to day farming activity and behaviour in old age.

- Future policies must take into account the emotional well-being of elderly framers and work within this structure to effect change.

\section{Introduction}

Interest in intergenerational family farm transfer and its impact on the farming economy has grown considerably amid concerns about the sustainability of an ageing farming population (Ingram and Kirwan, 2011). Global demographic trends reveal an inversion of the age pyramid with those aged 65 years and over 
Conway et al., 2016. Cease Agricultural Activity Forever? Underestimating the Importance of Symbolic Capital, Journal of Rural Studies, 44: 164-176

constituting the fastest growing sector of the farming community. In Europe, preliminary results from Eurostat's most recent Farm Structure Survey indicate that $6 \%$ of farmers were aged 35 and under in 2013, while over $55 \%$ were aged 55 and older (European Commission, 2013; European Commission, 2015). The situation in the Republic of Ireland is closely analogous to that of its European counterparts; in 2010 , only $6.2 \%$ of Irish landowners were under 35 years of age whilst $51.4 \%$ were over 55 years old (CSO, 2012). Between 2000 and 2010, those over 65 years increased by 31\%, while those within the 55 to 65 age bracket increased by $26 \%$, with a $52.8 \%$ reduction in the amount of farmers aged less than 35 years recorded (ibid). This 'greying' of the agricultural community, will see the number of aging farmers facing farm transfer accelerate in the coming decades (Mishra and El-Osta, 2007), a situation meriting serious and timely investigation.

Intergenerational farm transfer is a multifaceted process that encompasses three distinct but interrelated processes: succession, inheritance and retirement (Gasson and Errington, 1993). Succession is viewed as managerial control which is gradually relinquished; retirement is associated with the owner withdrawing from active participation in the business of the farm, while inheritance is the final stage when all of the business assets are legally transferred to the successor (Errington, 2002). Whilst conceptually separate, these processes are linked, with succession seen as the 'mirror image' of retirement; as the new generation succeeds, the old generation retires (Gasson and Errington, 1993; Errington and Lobley 2002; Uchiyama et al., 2008, Lobley, 2010). The terms 'succession' and 'retirement' will thus be used interchangeably throughout this paper.

Intergenerational family farm transfer is a complex and highly topical issue both in terms of society and farm sustainability. A low rate of entry into farming will lead to fewer numbers of farmers and may have profound implications for the industry, the countryside, land use and the broader sustainability of rural communities (Ingram and Kirwan, 2011; Goeller, 2012). Equally, it has been recognised that the 'twin process' of succession and retirement if not addressed adequately can be a period of considerable stress, 
both emotionally and financially, for family farm households (Burton and Walford, 2005). More broadly, many investigations of intergenerational family farm transfer have limited attention to the lack of successors willing to take over, despite the well documented deep-rooted reluctance by elderly farmers to transfer managerial duties to younger generations and retire from farming (Gasson and Errington, 1993; Kimhi and Lopez, 1997; Gillmor, 1999; Foskey, 2005; Bika, 2007; Lobley et al., 2010; Bogue, 2013; NRN, 2013). The prevailing reason for an aging farming population from census to census is also reported to be the lack of 'new blood' entering the industry (ADAS, 2004; Hennessy and Rehman, 2007; DGIP, 2012; Zagata and Lošilák, 2014). However, despite changes in agricultural support regimes, challenging economic environments and sociocultural changes in farming, the upsurge in demand from young people for education and training in agriculture in the Republic of Ireland and beyond provides contradictory evidence and indicates a renewed interest in pursuing farming as a career (Teagasc, 2011; Whitehead et al., 2012; Baker, 2012). Therefore, while the successor is undoubtedly a crucial player in the succession and retirement planning process, it is crucial to realise that the successor is not alone in resisting the process. In many cases the older generation also experience difficulties actively engaging in or mobilising the process and as a result often exerts strong pressures to avoid the emotionladen issues of succession and retirement (Lansberg, 1988). A particular focus of this paper therefore centres upon the notion that older farmer's emotions are not given due consideration (Kirkpatrick, 2013) when discussing the interrelated processes of intergenerational family farm transfer: succession, inheritance and retirement.

Undue emphasis on economic aspects of intergenerational family farm transfer has led to an overly simplified view of the factors influencing the decisionmaking process. Agricultural policy, designed to assist older farmers to exit farming focuses on encouraging those generating low returns to retire from the industry but these are clearly not designed to deal with the specific issues facing ageing farmers (Rogers et al., 2013). This human dynamic is disregarded with little value placed on the notion that farming is not just a job or something driven by a desire to make money; it is a passion and a 
lifestyle (ibid). A byzantine mix, whereby the already problematic economic business dimension is further complicated by a more complex emotional aspect. It is naïve therefore of policy makers and practitioners not to consider the potent mass of emotional and psychological values attached to the farming occupation for older farmers 'beyond the economic' (Pile, 1990, p. 147).

To explore this further, family firm literature containing a plethora of research concerning the psychodynamic and sociodynamic factors that influence and hinder the succession and retirement process from the perspective of the senior family business owner and leader, hereafter referred to as the incumbent (e.g. Christensen, 1953; Kets de Vries, 1985; Ward, 1987; Lansberg, 1988; Handler, 1994; Sharma et al., 2001; Kets de Vries, 2003; Sharma et al., 2003; Palliam et al., 2011) will be drawn on. The psychodynamic approach, originally developed by Sigmund Freud in the late 19th century, emphasizes the interplay of unconscious psychological processes in determining human thought, feelings, and behaviour which ultimately shape ones personality (Bernstein et al., 2006). While psychodynamic emotions concern individual's sense of self, sociodynamic emotions are seen as dynamic systems that emerge from the interactions and relationships in which they take place (Mesquita and Boiger, 2014). Of great interest here is that an incumbent's dominant control over the firm makes them adjourn and defer succession and retirement planning 'for lifestyle, psychological, and behavioural reasons' and thereby they often become the most significant barrier to the process (Palliam et al., 2011, p. 27). This paper, in particular, draws on Lansberg's (1988) theoretical hypotheses of resistance to succession and retirement planning in the family business from the perspective of the incumbent. According to Lansberg's theory, resistance or at best ambivalence towards the process can be explained by the understanding that succession decisions tend to be emotionally loaded (ibid).

There is however no great depth of research that explores these issues in relation to the family farm business resulting in a clear lack of understanding of the views of elderly farmers, on their concerns, fears, needs and future plans. Drawing on two previously disparate literatures (transferring the family firm 
Conway et al., 2016. Cease Agricultural Activity Forever? Underestimating the Importance of Symbolic Capital, Journal of Rural Studies, 44: 164-176

and family farm), this paper sets aside financial enticements and presents a more nuanced analysis of the factors that influence the unwillingness and reluctance amongst older farmers towards relinquishing management and ownership of the family farm and ultimately begin the process of their retirement (Gillmor, 1999; Bika, 2007; Ingram and Kirwan, 2011). In addition to the policy-related contribution of this study, this paper is theoretically innovative in using Bourdieu's notion of symbolic capital (i.e. resources available to an individual on the basis of esteem, recognition, status, or respect in a particular social setting) (Bourdieu, 1986) to comprehend the human factors governing the behaviour patterns of elderly farmers. Indeed according to Glover (2011), symbolic capital is ideological, relating to a farmer's sense of identity and giving them a 'sense of belonging in society' ( $p$. 9). Therefore instead of focusing on the 'mechanics' of family farm transfer (Price and Conn, 2012), we aim to dissect the role that emotional ties to the farm and farming occupation play on decision-making processes surrounding farm succession and retirement from the older farmer's perspective. Consequently, this paper has global relevance and will be of particular interest to countries like the Republic of Ireland where the age profile of the farming community and the rate of succession and retirement have been matters of concern and unease for decades (Commins, 1973; Commins and Kelleher 1973; Gilmor, 1999; Bogue, 2013; NRN, 2013).

The next section reviews the family firm and family farm transfer literature. This is followed by an outline of the theoretical framework adopted and a summary of the methodology employed in the research. Research findings are then discussed with the latter part of the paper drawing some exploratory conclusions.

\section{Transferring the Family Firm and Family Farm}

\section{Literature Review 2.1. 'Greying' of the Farming}

\section{Population}

The farming community increasingly consists of a farm population with a 
high age profile. This 'greying' of the farming population has major implications for government policy (Rogers et al., 2013) raising concerns about the need to reinvigorate the industry with new, or at the very least fresh, blood, alongside arguments that an elderly farming population is likely to be less competitive in the current market place because they are slower to adopt new innovative agricultural technologies (Ingram and Kirwan, 2011). In the Republic of Ireland for example, it is argued that significant changes and modifications to boost the competitiveness and production efficiency of Irish agriculture through land mobility (i.e. transfer of land from one farmer to another, or from one generation to the next) and structural change are required in order to realise ambitious growth targets set out in Food Harvest 2020 (DAFF 2010; Läpple and Hennessy 2012; Bogue, 2013; NRN 2013). Specifically, not unlike elsewhere in the world, there have been calls for deterrents obstructing the passage of farmland from the older to younger generation of farmers to be overcome as the intergenerational transfer of the family farm is viewed as crucial for future prosperity in the farming industry (Connolly, 2009). In the Republic of Ireland however, the owner- operator of land tenure is particularly inflexible because entry to the sector is almost entirely by inheritance or purchasing land; entry via leasing of land or partnership arrangements, common in many countries throughout the world, are not widely practiced (NESC, 1997; Hennessy and Rehman, 2007). A recent report on 'Land Mobility and Succession in Ireland' claims the lack of land mobility currently experienced is stifling agricultural growth and development by preventing young 'enthusiastic' farmers gaining access to productive assets (Bogue, 2013). In an effort to alleviate concerns of an aging farming population and improve competitiveness, the Irish policy environment has explored various methods of stimulating and enticing intergenerational family farm transfer for some time. These included several well-documented financial incentives which encouraged early retirement from farming, albeit very little change in attitudes towards intergenerational transfer of the farm has come about (Ryan, 1995, Gillmor, 1999; Bika, 2007). Early retirement schemes have had only marginal success in restructuring the farming sector. Ryan (1995) suggested weak participation was the result of several factors including low retirement benefits and a cultural resistance to leave farming. Other attempts included 
a concerted effort to ensure the most tax efficient means of transferring ownership and wealth of farms (Meehan, 2012), which again yielded nothing like the required result. In fact, despite these financial incentives, reluctance of older farmers to exit or retire from the farming sector to facilitate young farmers who have a desire to start up persists.

The acceptability of retirement schemes from farming is likely to be a personal dilemma for many elderly farmers particularly as they adjust to a major change in their occupational role (Commins, 1973; Gillmor 1999). Understanding when to relinquish control from the family farm can be difficult to recognise for many farmers in that few other businesses generate the emotional connections that farming does (Kirkpatrick, 2013; Rogers et al., 2013). Farming life throughout the world is characterised by the almost inseparable intimate integration of home, work, memories and family tradition (Barclay et al., 2012; Kirkpatrick, 2012; Uchiyama and Whitehead, 2012). In fact, Lobley et al. (2004) and previously Gillmor (1977; 1999) pointed to distinctive characteristics of farmers, in that they tend to have deep rooted emotional attachment to the key business assets they own, such as particular tracts of land or animals, thereby increasing their reluctance to relinquish ownership and leave farming. Kirkpatrick (2013) argues that in many cases the older farmer's sense of place and purpose attached to the family farm supersedes economic imperatives encouraging the transfer of the family farm to the next generation. This indicates the overwhelming significance of lifestyle over profit (Price and Conn 2012). Recent research conducted in the Republic of Ireland, touched on this, alluding to the fact that 'apart from the economic driver of payments retaining elderly farmers on land, there are also psychological drivers involved' and 'addressing the issue of low levels of mobility must also take cognisance of these psychological barriers' (NRN, 2013, p. 6). This research came 40 years after Commins (1973) first stressed that retirement policy, 'with economic objectives, should not ignore possible social consequences or wider issues of human welfare' (p. 45). However, to date, such recommendations have largely been ignored, resulting in the formulation and implementation of largely unsuccessful farm transfer policy strategies, such as Early Retirement Schemes, which have little or no regard for elderly farmer's emotions. It is in probing these issues further that this paper now turns. 
Conway et al., 2016. Cease Agricultural Activity Forever? Underestimating the Importance of Symbolic Capital, Journal of Rural Studies, 44: 164-176

\subsection{Propensity of the Incumbent to Step Aside and Retire}

The incumbent who hands over the leadership role of the family business and the successor, who takes over, are the two key stakeholders in the succession process (Sharma et al., 2001; Whitehead et al., 2012). Since Christensen's (1953) study of succession planning and management in family businesses, this issue has gained significant prominence (Handler, 1994; Brockhaus, 2004) and is now an essential subject matter of research in family business literature (De Massis et al., 2008). Succession is seen to be the ultimate test of success for the family firm (Glover, 2011), with significant practical implications for the continuity of the firm (Handler, 1990). In general, the indications are that the degree to which a family business engages in the succession process is positively influenced by the propensity of the incumbent to step aside and the presence of a capable successor to take over the firm (Danco, 1982; Palliam et al., 2011). Sharma et al. (2001, citing Hofer and Charan, 1984) note however that the likelihood of a successful professional management transition is practically zero if the incumbent is not committed to the process. Similarly in relation to retirement, Sharma et al. (2001) highlight that the extent of effective intergenerational transfer planning in family businesses is directly related to the incumbent's plan to retire from the firm. Indeed as far back as the 1950s, Christensen (1953) argued that 'the first and foremost barrier that stands in the way of some provision for retirement planning, is the top manager himself' (p. 129). Therefore, the responsibility for directing succession and retirement planning lies heavily on the support of the incumbent (Christensen, 1953; Lansberg, 1988; Kelly et al. 2000; Palliam et al., 2011), who appears to have 'the power to shape the succession process for better or ill' (Sharma et al., 2001, p. 31).

From a family farming perspective, there is evidence of negative consequences that may occur if the older farmer is unable to release control of the family farm (Potter and Lobley 1992; Errington and Lobley 2002). It has been argued that failure to do so can have adverse impacts on not only the development trajectory of a farm but also the productivity and innovativeness of the agricultural industry as a whole (Gillmor, 1999; Lobley, 2010) As such, optimal timing is considered crucial to a successful family farm transfer (Lange, et al., 
2011). A potential difficulty in passing on the legacy of the family farm is that successors are ready to begin their careers, but parents are not always ready to hand over the farm (Keating, 1996). According to Keating (1996) 'while some farmers plan to retire in their late sixties, many do not expect to retire at all' (p. 414). Research suggests that the older generation's decision to never retire or only semi retire is impacting on the younger generation's ability to embark on a true and meaningful career path of full time farming, and under such incidences it could take 20 years for them to assume management of the farm (Keating, 1996; Kirkpatrick 2012). This is a major concern as recent research carried out in the UK by ADAS (2007) indicates that younger farmers are becoming increasingly impatient as they yearn for greater independence, recognition and opportunities for leadership on the family farm.

Such arguments have led family business researchers to the hypothesis that initial satisfaction with the succession process will 'depend on the extent to which an incumbent is willing to step aside' (Sharma et al., 2001, p.23). Ultimately, this requires a mental withdrawal from the business as much as a physical withdrawal (Whitehead et al., 2012, p. 220). If an incumbent is willing to do this, 'a major impediment would be removed' (Palliam et al., 2011, p.27) and 'the likelihood of a satisfactory succession process increases because such willingness indicates the incumbent's acknowledgement that new leadership is needed and, possibly, acceptance of the successor as a suitable replacement' (Sharma et al., 2001, p.23). Unfortunately, however, the intergenerational transfer experience of most is 'one of frustration, conflict and unfulfilled dreams' (Glover, 2011, p.4) as the incumbent is unwilling to delegate sufficient responsibility to the younger generation (Kets de Vries, 1985; Lansberg, 1988; Sharma et al, 2001). A major concern is that potential successors may lose interest and motivation continually working in the incumbent's shadow and therefore decide to leave the family firm in pursuit of more fulfilling opportunities elsewhere, resulting in the self-destruction of the business (Simms 1988; De Massis et al. 2008). This phenomenon is known as 'corporeuthanasia' which Danco (1982) defines as 'the owner's act of wilfully killing off the business he loves by failing to provide in his lifetime for a viable organization with clear continuity (p.5). Similarly from a family farming 
perspective, Kirkpatrick (2013) notes that 'farm operations that would be considered financially sound, well-managed businesses can slowly collapse and fail because the older generation is unable or unwilling to face the contradicting desires of seeing the next generation succeed yet retain the independence and self-identity farming provides' (p. 3). Goeller (2012) also warns that 'without thoughtful planning for succession, the unintended consequence is that there are fewer and fewer young farmers entering the business and ownership of land becomes concentrated into fewer and older hands' (p.150) which can also have adverse effects on the sustainability and indeed survival of rural communities (ibid).

\subsection{The Incumbent's Resistance to Succession and Retirement}

While the incumbent is often aware of the need for devising a succession plan, they can experience overwhelming personal psychodynamic and sociodynamic deterrents against managing their exodus from the family business and thus fail to prioritise it (Lansberg, 1988; Sharma et al, 2001). A recurrent theme in family firm literature involves attempting to comprehend why the incumbent has difficulty and indeed is unable to 'let go' their control and power to dictate the daily running of the business (e.g. Kets de Vries, 1985; Lansberg, 1988; Handler, 1990; Handler, 1994; Sharma et al., 2001; Kets de Vries, 2003). In family businesses, leadership, centrality and power have been identified as central needs for the incumbent (Lansberg, 1988, Kets de Vries, 2003). Kets de Vries (1985) suggest that in many cases, an incumbent may resist intergenerational management transitions because they have difficulty envisaging life without an important management position in the family business. For an incumbent, surrendering leadership of the firm and dissociating oneself from the business is often 'experienced as the first step toward losing control over life itself' (Lansberg, 1988, p.124). In addition, an incumbent may also be reluctant to step aside and relinquish control and ownership of their business because this would be surrendering their identity (Lansberg, 1988; Sharma et al., 2001). As the incumbent has spent a substantial proportion of their lives, not just their career, developing and operating their business, it is often their most significant creation and it has 
Conway et al., 2016. Cease Agricultural Activity Forever? Underestimating the Importance of Symbolic Capital, Journal of Rural Studies, 44: 164-176

grown to become an integral part of their inner self, giving them meaning and a sense of purpose in life (Lansberg, 1988, Palliam et al., 2011). The more central an incumbent's work role is connected to their overall sense of self and purpose, the more adverse their retirement expectations are (Gee and Baillie, 1999; Handler and Kram, 1988; Gagne et al., 2011). An incumbent may also resist the process as they fear 'losing status in the family and the community as both may be closely intertwined with his or her role in the family business' (Sharma et al., 2001, p. 22). Potential change to business values and philosophy, management styles and an inability to face his or her mortality further exacerbate these difficulties (Lansberg, 1988; Simms 1988; Sharma et al., 2001, Kets de Vries, 2003, McLeod, 2012). Combined, these factors negatively influence the incumbent's motivation and ability to exit the business.

Similarly, drawing on the family farm transfer literature from Ireland and further afield (Gasson and Errington, 1993; Kimhi and Lopez, 1997; Gillmor, 1999; Defra, 2002, Vare, 2006; Bika, 2007; Calus et al., 2008; Lobley et al., 2010; Ingram and Kirwan, 2011; Barclay et al., 2012), it is clear that in spite of the inherent desire to keep the family farm in the family, there is considerable reluctance and resistance amongst the older generation towards relinquishing control and ownership and retiring. Consequently, there is a lack of land mobility (i.e. access to land) leading to an inevitable decrease in the number of farm transfers. In the Republic of Ireland for example, entry to farming through channels other than inheritance is rare due to both the limited availability and the high cost of land (Hennessy and Rehman, 2007). It is estimated that only 0.3\% of the total land area in Ireland was put on the market in 2011 (Irish Farmer's Journal, 2012). However, succession and particularly retirement is also recognised as a major transitional challenge for the older generation of farmers. According to Price and Conn (2012), 'allowing for succession is an emotional rather than rational process (p. 101), because for many, farming is a not just a profession but a 'way of life' (Barclay et al. 2012; Price and Conn, 2012). 
Conway et al., 2016. Cease Agricultural Activity Forever? Underestimating the Importance of Symbolic Capital, Journal of Rural Studies, 44: 164-176

\section{The Importance of Symbolic Capital}

A key aspect of this discussion is to consider the role that Bourdieu's concept of symbolic capital plays on the emotional capacity of elderly farmers to accept the inevitable challenges and changes brought about by intergenerational transfer of the family farm. Bourdieu, essentially concerned with what people do in their day-to-day lives (Jenkins 1992), introduced the concept of symbolic capital in his analysis of social relationships in pre-capitalist, agrarian societies (Forest and Johnson, 2002). Although this idea has been applied more broadly in sociological research, and across a range of social issues, part of Bourdieu's appeal, is that his work is so prolific and empirically documented. Despite this however, there has been little or no research carried out internationally, on the link between symbolic capital and intergenerational family farm transfer. Additionally, there has been limited research carried out on this potential correlation from a family firm perspective.

Before discussing the core theoretical framework, it is necessary in the first instance to introduce Bourdieu's primary 'thinking tools' premising the sociology of everyday life, a complex theoretical triad consisting of 'habitus', 'capital' and 'field' (Bourdieu, 1977). These three cornerstones of Bourdieu's theory of practice (Emirbayer and Johnson, 2008) interrelate with each other, both conceptually and empirically (Bourdieu and Wacquant 1992), as exemplified by the following formula for studying social practice: '(Habitus $\mathrm{x}$ Capital) + Field $=$ Practice' (Bourdieu, 1984, p. 101). This equation can be qualified as: 'practice results from relations between one's dispositions (habitus) and one's position of power (capital) within the current state of play of that social arena (field)' (Maton, 2008, p.51). As an agent is positioned within a field by virtue of their total accumulation of symbolic capital, which can be gained from any combination of capital available to them in society (Nicholls, 2005), and the practices one engages in to accumulate (this type of/such) capital is structured by their habitus (Zarei and Pirnajmuddin 2014), this pseudo-mathematical equation helps us to see how symbolic capital cannot be detached from Bourdieu's interlocking conceptual arsenal and must be understood as a relational concept (see Fig. 1). 


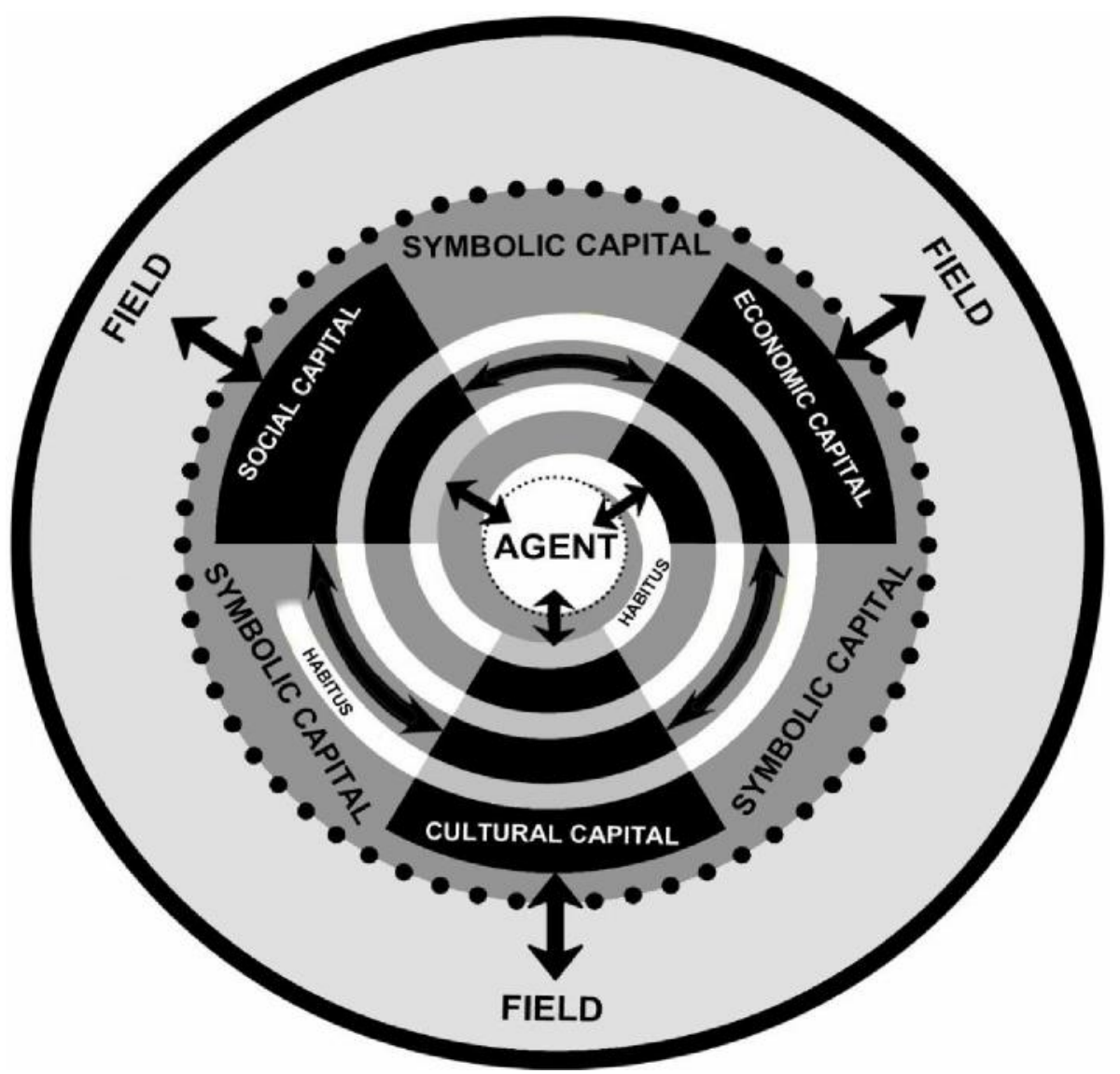

Fig. 1: Diagrammatic representation of symbolic capital illustrating its relationship with the rest of Bourdieu's interlocking concepts.

In economic thought, the term capital originally meant 'an accumulated sum of money, which could be invested in the hope of future profits' (Field, 2003, p. 12). According to Fuchs (2003) 'what distinguishes Bourdieu from orthodox forms of Marxism is that he does not reduce all aspects of social life to the economy' (p. 391). Bourdieu (1986) asserts that it is in fact 'impossible to account for the structure and functioning of the social world unless one reintroduces capital in all its forms and not solely in the one form recognized by economic theory' (p. 242). On the structural level of society Bourdieu (1984) therefore distinguishes four different types of distinct, yet inextricably linked forms of capital, each of which can be utilised by an agent in a social field: economic capital in the sense of Marx (money, profits), cultural capital (namely knowledge and skills), social capital (acquaintances, networks and social connections) and symbolic capital. Symbolic capital is constituted when the different forms of capital (economic, social and cultural) are socially perceived and recognized as legitimate bases for claiming esteem, 
honour, prestige, respect and recognition within a given field (Bourdieu and Wacquant, 1992). This derivative form of capital also gives symbolic power (form of authority) over other agents within a field. According to Swartz (1997), symbolic capital is 'a form of power that is not perceived as power but as legitimate demands for recognition, deference, obedience, or the services of others' (p. 90). A key property of symbolic capital is that it is not strictly intrinsic in an individual, but in fact developed as a result of social interaction (Christian and Bloome, 2004). Webb et al., (2002) explain that 'prestige and a glowing reputation, for example, operate as symbolic capital because they mean nothing in themselves, but depend on people believing that someone possesses these qualities' (p.xv). Üstüner and Thompson (2012) go on to state that 'symbolic capital is a sociological phenomenon rather than a strictly psychological one. That is, the field-specific conditions that legitimate particular forms of capital transcend the idiosyncratic judgements of a given individual' (p.797).

\subsection{Theorising Symbolic Capital at Farm Level}

Although the concept of symbolic capital has not been explicitly used in the discussions of family farm transfer to date, several analogous strands of research demonstrate the value of symbolic capital in the field. Burton (2004) for example, suggests that land allows expression of identity for the farm family and symbolically becomes an integral part of the farmer/farm family. Symbolic capital also comes to the fore in times of crises; driving the need to continue business operations through critical incidences, a classic example being the 2001 Foot and Mouth crises (Glover, 2011). Glover (ibid) found that a key element to business survival during these difficult periods resulted in an inherent need to maintain symbolic capital, which in turn embeds a farmers' place in society with their unique identity remaining in place. Bourdieu's concept of symbolic capital therefore provides a useful lens for exploring the human factors that influence family farm succession and the retirement decisionmaking processes as it concerns 'the prestige and renown attached to a family and a name' (Bourdieu, 1977, p.179). The negative consequences associated with the potential loss of an older farmer's symbolic capital due to 
Conway et al., 2016. Cease Agricultural Activity Forever? Underestimating the Importance of Symbolic Capital, Journal of Rural Studies, 44: 164-176

transferring the family farm are real, but underappreciated, by policy and indeed society as a whole. In using symbolic capital as a lens through which we can explore the challenges of intergenerational family farm transfer, the following section details the way in which this plays out on the ground. 


\section{Methodology}

Staying true to its geographical foundations, this research employed a multi-method triangulation design in an attempt to secure an in-depth understanding of the psychodynamic and sociodynamic factors that influence the process of transferring the family farm business from the perspective of the senior generation. Cohen and Manion (1986) define triangulation as an 'attempt to map out, or explain more fully, the richness and complexity of human behaviour by studying it from more than one standpoint' (p. 254). For the purpose of this study triangulation was assured using a collection of both quantitative and qualitative data through the use of self-administered questionnaires in conjunction with complimentary Problem-Centred Interviews. Approaching the research phenomenon from two different yet co-equal and interdependent methodological vantage points counteracts the limitations and biases that stem from using a single method, thus increasing the validity and reliability of findings (Babbie and Mouton, 2001).

A detailed survey was initially undertaken with farmers in attendance at a series of 'Transferring the Family Farm' clinics hosted by Teagasc, the agriculture and food development authority in Ireland to investigate the behavioural intentions and attitudes of older farmers towards succession and retirement from farming. These clinics facilitated by Teagasc, took place at 11 locations throughout the Republic of Ireland in September and October 2014, with local solicitors, accountants and other experts also in attendance for one to one meetings with attendees. These events also provided an ideal opportunity to recruit participants located throughout the Republic of Ireland for interview at the second phase of data collection. Representatives from each of Teagasc's advisory service regional units organised and participated in these clinics (delivered free of charge) following a series of seminars and a successful pilot event in February 2014. As part of Teagasc's campaign to advertise and promote these 'Transferring the Family Farm' clinics, invitations were sent out to each of their 43,000 farming family clients to attend. This sample therefore provides an acceptable nationally representative sample of the Irish farming population across a range of diverse regions, farm sizes and operations. It is acknowledged however, that a degree of potential bias may exist in this sample towards those who are considering the idea of farm transfer.

Prior to the distribution of self-administered questionnaires at these clinics, a draft questionnaire was initially developed, pretested, and revised where necessary to strengthen reliability (Creswell, 2005). This design approach resulted in a self-administered questionnaire that communicated the desired message effectively and obtained, as far as was verifiable, reliable responses from farmers in attendance at these clinics. In addition to probing the succession and retirement intentions of older farmers, survey respondents were also asked to state the degree to which they agreed or disagreed 
with a set of statements, measured on five-point Likert scales. Based on a review of family firm and family farm literature, these psychometric scales drew on factors that influence and hinder the succession and retirement process from the perspective of the senior generation. The statements therefore tested a number of hypotheses expressed in this paper by providing an insight into: (i) older farmers' attitudes and opinions regarding the transfer of the family farm to the next generation and (ii) their emotional connection to their farm and occupation. In addition to eliciting the personal views of farmers, the survey collected respondents' relevant socio-demographic information. Survey participants were also given the option of supplying their contact details for interview at the next stage of the research process. In terms of data analysis, questionnaire data were coded and then analysed using frequency distribution tables and a series of cross-tabulations performed in the Statistical Packages for Social Sciences (SPSS) programme.

In order to validate, deepen and build on the quantitative data gathered at the Transferring the Family Farm Clinics, the second phase of data collection consisted of a Problem-Centred Interview approach (Witzel, 2000). Witzel (2000) explains that Problem-Centred Interviews can be combined with questionnaires in order to 'solve the problems arising in connection with samples and to relate the results generated by different procedures' (p. 3). This qualitative methodology presented a viable approach to further investigate the behavioural intentions and attitudes of older farmers towards succession and retirement from farming as it gathers objective evidence on human behaviour as well as on subjective perceptions and ways of processing social reality (Witzel, 2000). Although Problem-Centred interviews contain open ended questions to ensure that respondents can freely and extensively produce a relatively natural dialogue, one of the key principles of this form of interview is that it is centred upon a specific social phenomenon that the interviewer keeps in mind throughout the conversation. A predetermined Problem-Centred Interview guideline therefore allows for a greater emphasis on the specific aspects of the issue that needs to be analysed, which might not be tackled in a narrative interview setting (Scheibelhofer, 2005). This methodological tool also provides a framework of orientation to ensure comparability of interviews (Witzel, 2000). Following frequency distribution and cross-tabulation analysis of survey data obtained at the Teagasc clinics, in conjunction with an additional review of relevant literature in the field, it was possible to draw up a specific Problem-Centred Interview guideline containing pre-formulated questions on the issues that were identified to be subjectively significant to the sample farming population. Given the personal nature of the issues under investigation the use of individual face-to face interviews was deemed the most appropriate means of obtaining information from the senior generation of the farming community. All interviews were carried out in the homes of the respondents from May until August 2015. The interviews lasted up to 2.5h and were tape recorded, transcribed in full and assigned pseudonyms to protect participant's privacy. Content analysis (Mayring, 2000) was used to analyse the data collected and identify categories and themes. Relevant 
Conway et al., 2016. Cease Agricultural Activity Forever? Underestimating the Importance of Symbolic Capital, Journal of Rural Studies, 44: 164-176 quotes from the interviews were then integrated into the various themes in order to support particular findings.

\section{Results and Discussion}

The presented findings are the result of a triangulation of quantitative survey data obtained at the Teagasc Transferring the Family Farm clinics and complimentary Problem-Centred interviews questions formulated upon an analysis of survey data and relevant literature in the field. Over 2,800 farmers attended the 11 clinics and all of the 417 farmers who were randomly selected and then approached to participate in the study agreed to complete the questionnaire, resulting in a $100 \%$ response rate. However, as older farmers are the target population of this study, only respondents aged 55 and over have been included in the analysis. The reasoning for specifically focusing on farmers aged 55 and over is that one of the terms and conditions for farmers intending to retire under the Early Retirement Scheme (ERS 3) launched in Ireland in June 2007 was that participants must have been between the ages of 55 and 66 to be eligible. Questionnaires with missing data were also eliminated from the survey to avoid biased statistical results. After both these processes, a total of 324 complete questionnaires qualified for analysis. $60 \%(n=194)$ of these respondents also gave their consent to be interviewed more indepthly. A $10 \%(n=19)$ sample of these farmers located throughout the Republic of Ireland were sourced and subsequently interviewed using a systematic sampling technique (see Table 1). The overriding themes to emerge from the content analysis of the empirical research were farmers' concerns regarding potential loss of personal identity and stature and the fear of losing their positional control upon transferring their farm and retiring from farming. Problem-centred Interviews with farmers also highlighted the divergence of opinion and uncertainty between retirement expectations and retirement realisations, resulting in the decision to retire being difficult to execute and follow through. 


\begin{tabular}{lcclcc}
$\begin{array}{c}\text { Pseudo } \\
\text { Name }\end{array}$ & Gender & Age & \multicolumn{1}{c}{ Farming Enterprise } & $\begin{array}{c}\text { Regional } \\
\text { Location }\end{array}$ & $\begin{array}{c}\text { Considered } \\
\text { Retirement }\end{array}$ \\
\hline Frank & Male & 57 & Mixed livestock & West & Yes \\
Luke & Male & 69 & Mixed Livestock & West & Maybe \\
Dominic & Male & 77 & Mixed Livestock & West & Maybe \\
Rory & Male & 66 & Sheep & West & No \\
Andrew & Male & 64 & Beef & West & Maybe \\
David & Male & 70 & Beef & North West & Maybe \\
Thomas & Male & 80 & Sheep and Tillage & North West & Yes \\
Sean & Male & 75 & Dairy and Poultry & North East & No \\
Mark & Male & 61 & Dairy & East & No \\
Claire & Female & 82 & Mixed Livestock and Tillage & East & No \\
Josh & Male & 70 & Tillage & South East & Yes \\
Jack & Male & 72 & Dairy & South East & No \\
lan & Male & 67 & Dairy & South & No \\
John & Male & 70 & Mixed Livestock & South & No \\
Colm & Male & 71 & Mixed Livestock & South West & No \\
Eimear & Female & 65 & Beef & South West & No \\
Brian & Male & 85 & Dairy & Midlands & Yes \\
Richard & Male & 67 & Beef & Midlands & Yes \\
Aoife & Female & 68 & Mixed Livestock & Midlands & No \\
\hline
\end{tabular}

Table 1: Interviewees' Details

Findings from the questionnaires carried out at the Teagasc clinics indicate that $33 \%(n=108)$ of the total number of respondents over the age of 55 in attendance have not considered retiring from farming in the future. $45 \%$ ( $n=145)$ stated that they have considered retiring while $21 \%$ of farmers $(n=67)$ were uncommitted in their answer. 1 farmer did not have any opinion on the matter. As these clinics were geared towards farmers who are considering transferring their family farm, one would expect that the majority of those in attendance would be open to the idea of retirement, however as these findings illustrate, one third of respondents had not even considered it. ProblemCentred Interviews conducted with farmers shed some light on why this is the case. Interviews reveal that the farm and farming occupation completely encapsulate the lives of many farmers. 72 year old dairy farmer Jack from the South East of Ireland has no intention of retiring from farming, despite being in an official farm partnership with his son:

'Have I considered retiring? Never... I couldn't, I just couldn't! I'd be always saying I'll take it easy, but I couldn't, I have that drive to keep going like.... shur I am up every morning at half 6 and I could be going until 10 or 11 o'clock at night, so I couldn't even imagine it. I make out it wouldn't be good, because I think it's important to be active, I enjoy it like. I like to farm. But if I had to retire, it would not be for a few more years; I'm only 72 like, so definitely not for a few more years'. 
Similarly, Colm, a 71 year old mixed livestock farmer from the South West of Ireland who also farms in partnership with his son refuses to even consider the thought of retirement:

'Oh god no, they'd take me out legs first... I would find it very difficult if I was told tomorrow morning, ok you can't go farming anymore. I think that would have a major effect on my life. I wouldn't even like to go down that road, I wouldn't even consider it... not being involved in farming? It is my life like!'

Interestingly, 32\% of the 145 questionnaire respondents who considered retiring in the future agreed that they could not imagine what they would do if they permanently ceased all farming activity. Furthermore, $64 \%$ of these farmers also agree that the lifestyle quality from being a farmer is far greater than can be quantified by any financial incentive to leave farming. This pattern of findings is consistent with psychological research, showing that attitudes are not necessarily related to behaviours (e.g., Ajzen, 1991). Luke, a 69 year old mixed livestock farmer from the West of Ireland admitted that he had thought about retiring, but quickly dismissed the idea:

'Well I would think about it sometimes, but shur where am I going to retire to like? It's what I do and it is all I know what to do. Tis fine you could go on holidays there for a week or 10 days, my wife and I often did, but you would just be delighted to go back to the farm, back doing something again, besides doing nothing.... It's hard to retire from farming, because you are always pottering around yanno, it is not possible to retire or leave... I couldn't possibly imagine what I would do next'.

Similarly, 57 year old part time mixed livestock farmer Frank also from the West who has two sons interested in taking over the family farm explained:

'Although I am actively thinking of retiring or in the process of it, I really won't be retiring... I don't think it would be good right now for me, I think that if I had nothing to go to it would be a sad day. I see a lot of farmers who loose themselves when they retire... you need to have some interest in it, even if your sons have taken over you need to be there helping them and keeping active rather than just throwing in the towel. I think it is a bad idea to just walk away completely'.

These findings also mirror previous family business research by Gagnè, et al. (2011) who found that the planned retirement date of incumbents was unrelated to their attitudes toward retirement or to their concrete planning for retirement. According to Gagnè, et al. (2011) 'simply because business leaders have a date in mind for their retirement does neither mean that they perceive their retirement in a positive light nor that they concretely take steps to plan it' (p.300). The above mentioned prominent themes of (i) loss of personal identity, (ii) changes in social stature and (iii) difficulty relinquishing control that were identified as having a significant hindering and deterring influence on the process of transferring the family farm from the perspective of the senior generation will now be discussed. The themes will be linked to relevant issues in family farm and family firm transfer literature and effectively portrayed in selected comments direct from the 
interviewees. Findings from the empirical research also bring forth added credence to the perception that policy is 'underestimating the importance of symbolic capital' when discussing the issue of intergenerational family farm transfer.

\subsection{Loss of Personal Identity}

Results from the empirical research indicate that the potential loss of personal identity and selfesteem brought about by transferring managerial control and retiring from the family farm business, can have a delaying if not detrimental effect on the process. Convery et al. (2005) previously observed how farmers 'drew identity, self-esteem and well-being from their 'day-to-day' environment' (p. 102). 71\% of questionnaire respondents at the Teagasc clinics agree with the notion that farming is not only their job, but also their lifestyle, past time and social outlet. This allencompassing ideology of the farming occupation is aptly explained by Aoife, a 68 year old mixed livestock farmer interviewed from the Midlands of Ireland:

'Farming means everything. I get up in the morning to farm, I look out at the weather to see how it will affect my farming. Where I go, who I meet, who I talk to, everything is farming, it is my life, it makes me what I am_ It is my whole life, I don't have any other interests"

Research carried out by Rogers et al. (2013) also claim that for many farmers, their personal identity is deeply embedded in their land and occupation. Moreover, $87 \%$ of questionnaire respondents agree that the farm represents years of hard work and what they have managed to achieve over their lifetime while $68 \%$ agree that their farm and occupation have a greater symbolic importance than a financial one to them. Josh, a 70 year old tillage farmer from the South East of Ireland gives an insight into non-monetary values associated with the farm and farming profession:

'The farm means an awful lot to me, we have been here for 12 or 13 generations, we go back to 1725 , so it means a lot to me. It means a lot to me in the sense that I inherited it and I would never ever contemplate selling it... being able to farm it well and make a living out of it has given me a huge sense of satisfaction throughout my lifetime. I'll never be a millionaire but l've enough money to put food on the table and to live a good life and that's the most important thing'. 
Similarly, mixed livestock farmer Colm, from the South West explains:

II would like to be able to keep farming for as long as I can because I get so much enjoyment and pride out of doing it and as I've said umpteen times before, it's not about the money, the money is secondary'.

These findings also reinforce previous research by Ingram and Kirwan (2011) who maintain that 'older farmers are clearly attached to their farms, having put a lot of effort and investment over the years into building up the business' (p.295). While Rogers et al. (2013) argued that identity issues which influence farm management decisions cannot be explained by economics alone.

The notion of identity and the concept of symbolic capital, are closely connected (Swartz, 2013). According to Swartz (ibid), 'without symbolic capital, there is no identity since identity must emerge from insignificance and this can come only through successful elicitation of recognition from others' (p.105). As the incumbent's identity is often intensely intertwined with their farm or firm (Kets de Vries, 1985; Rogers et al. 2013), they may use their professional title as a 'distinctive mark' (Bourdieu, 1985) to identify themselves to others in their struggle for legitimacy and recognition in a field (Borthwick et al. 2015); i.e. 'I am a CEO' or 'I am a farmer'. Such an honorary position as head of the farm or firm is endowed with symbolic capital leading others to acknowledge their status (Bourdieu, 1985). 78\% of questionnaire respondents agree with the notion that being a farmer gives them a sense of belonging and a position in society. Problem-Centred interviews conducted with farmers discovered that the majority of interviewees felt that being identified as farmer is vitally important to their sense of self-esteem and self-worth in the farming community and the wider social world. For example, Mark, a 61 year old Dairy farmer from the East of Ireland explains that:

'Farming isn't just my job; it's a way of life for me. I am known far and wide as a farmer at this stage', I am not known as anything else. In fact, I wouldn't wish to be known or identified as anything else! I am proud to be a farmer and I would like to think that being a farmer defines who I am'.

These findings also reinforce Lansberg's (1988) argument that the family business can define an incumbent's position in their local community and society. As symbolic capital is perceptual, something that we, or others, feel that we are (Joppke, 1986), the potential dismissal of a lifelong title and position upon transferring the family farm to the younger generation may cause 'loss of face' within the family and community, thus, decreasing symbolic capital, and consequently leading older framers to resist the succession and retirement process. According to Formosa (2007), 'retirement forces older persons to an arena of role ambiguity' and 'strips them of their social worth in society' (p.11) thus diminishing their life-long accumulation of symbolic capital. Indeed, Formosa, (ibid) believes that once retirement age is reached, one's position in society is altered and a retiree's 'social space' changes from that of 'achievement' to one of 'ascription'. Previous identities and 
Conway et al., 2016. Cease Agricultural Activity Forever? Underestimating the Importance of Symbolic Capital, Journal of Rura I Studies, 44 : $164-176$ statuses associated with one's occupational position are erased and become meaningless (ibid). In response to the questionnaire's inquiry concerning this issue, $72 \%$ of respondents who had not contemplated retiring from farming in the future agreed with the suggestion that relinquishing control and retiring from farming would damage their identity and self-esteem. A number of farmers interviewed believed that they would be seen or perceived differently by others as a 'retired farmer' and therefore struggled to come to terms with the prospect of doing so. lan, a 67 year old dairy farmer from the South of Ireland recalled how another farmer's experience of an identity crisis upon retiring from farming has warned him away from the process:

'I can remember speaking to some fella a number of years back and he said that when he sold his farm and gave up farming that he was almost a non-identity afterwards, he wasn't a farmer anymore, he wasn't anything. He said that afterwards he never felt that he could go to farming meetings anymore because all his life he had been a farmer and next thing he wasn't and ya know that story made a major impression on me and has even influenced my own decisions to keep going and not retire ever since'.

These findings again endorse Lansberg's (1988) hypotheses that an incumbent may withstand succession planning 'out of fear of losing an important part of their identity' (p.124). Kets de Vries, (2003) also argue that 'the threat of going from somebody to nobody overnight, of being a nonentity experiencing nothingness, generates an enormous amount of anxiety (p.711).

\subsection{Changes in Social Stature}

In relation to loss of status, findings from the questionnaire also indicate that negative connotations associated with the idea of succession and retirement, especially at a time when the older generation seek purpose in life and feel needed, respected and valued as they age (Rogers et al., 2013) can become part of an older farmer's indoctrination, thus derailing the process. $87 \%$ of farmers surveyed, agree that 'the concept of retirement is not popular or well-regarded within the farming community', a situation unchanged from research carried out in the Republic of Ireland in the 1970s (Commins and Kelleher 1973; Commins, 1973). Following discussions with farmers on this issue, it became strikingly apparent that there seems to be a cultural expectation within the farming community that 'farmers don't retire'. Those who do retire are generally perceived by interviewees to have a defeatist attitude or else seen to have no option but to do so due to ill health. For example, mixed livestock farmer Colm, from the South West explains that:

'Farmer's don't retire. I'd say the only reason a farmer would retire is because of circumstances in their personal lives or their health... Then again there may be odd people out there who just like to retire and walk away from farming but they would be very much in the minority, I would imagine. I just think it would be seen as defeatist to retire'. 
Conway et al., 2016. Cease Agricultural Activity Forever? Underestimating the Importance of Symbolic Capital, Journal of Rura I Studies, 44: 164-176 Similarly, mixed livestock farmer Luke from the West claims that:

'Tis not popular, fellas always talk about retiring, fellas always say I am waiting for the day to retire, but they don't retire, do you see any of them retiring, I don't think so! I cannot see them retiring! It would be seen as having a lazy or defeatist attitude, definitely'

These findings are reflective of western society's failure to support incumbents who plan their succession and retirement from the family business (Lansberg, 1988; Kets de Vries, 2003). According to Lansberg (1988) 'the stereotypes that we carry are of legendary leaders who have 'died in the saddle' or 'gone down with the ship,' not of leaders who have thoughtfully planned their exit' ( $p$. 130). Therefore, planning for succession is perceived as a 'sign of weakness or as a deficiency of character', (Lansberg, 1988, p. 131) thus discouraging the incumbent to consider it. Lansberg (1988) found that even an incumbent who has plucked up the courage to fabricate a succession plan for their family business, 'often find themselves disoriented after their plan is made public' (p. 125). From a family farming perspective, Pitts et al. (2009) also observe that surrendering managerial control and ownership of the farm may 'reduce the status they have acquired in the community derived from being the primary operator' (p. 61), a position confirmed by $64 \%$ of questionnaire respondents who have not considered retiring from farming in the future. Numerous interviewees commented that they would feel isolated and separated from the rest of the farming community if they were to retire from farming. For example, 70 year old beef farmer David from the North West of Ireland explained that:

'If you give up farming you are gone, I mean you wouldn't be involved anymore. I think other farmer's wouldn't take a bit of notice of me if I retired and l'd imagine that they wouldn't have any interest in the world trying to talk to me about farming either because it would not be worth their while to do so anymore. I would be very conscious of that'.

Bourdieu (1990) explains that 'struggles for recognition are a fundamental dimension of social life' (p. 22) and highlights the importance of symbolic capital in an individual's social status. He argues that social life, and therefore business activity, may be conceived as a multi-dimensional status game (within which there are struggles for power); whereby individuals draw on three different types of resources (economic, cultural, and social capital) to compete for status (symbolic capital) (Holt, 1998). Over a farmer's lifetime of farming endeavours, they accumulate a significant level of status- conferring symbolic capital in the farming community (Glover, 2010). An underlying principle of the notion of symbolic capital implies that individuals derive their existence by living through others point of view; they become entangled in a web of total dependence on how others perceive them and how others define who they really are. This was evident within the survey results at the Teagasc Clinics with $71 \%$ of farmers agreeing that to maintain their status in the farming community it was hugely important that they were still viewed as a skilled, productive farmer amongst their peers. Regardless of their age, each farmer interviewed emphasised the essential role that they continue to have in the day-to-day operation of the farm. The majority of interviewees also plan to use their experience and skill to compensate for decreases in physical strength inevitable with age. For example, tillage farmer Josh from the South East explained that he will continue to play a key role in the farm even when he is no longer physically able to provide manual labour: 
Conway et al., 2016. Cease Agricultural Activity Forever? Underestimating the Importance of Symbolic Capital, Journal of Rura I Studies, 44: 164-176 'Generally speaking I would say that while you can do hands on farming, which I've done for the past 40 years or 50 years, keep doing it and when you are unable to do so you can always have an input from a management perspective and from an experience perspective.... That way you can still have an influence and play a productive role in the farm'.

Similarly, part time mixed livestock farmer Frank from the West would like to remain active and productive on the farm even upon transferring over the farm to the next generation:

'Even if the boys take everything over in the morning, I would still like to remain active and productive on the farm. Maybe not as much as I used to but I would still like to get out there on the farm and do some work... Not necessarily for monitory gain but to be active in yourself, because if you had nothing to get up out of bed for in the morning, it's a sad day'.

Rossier (2012) previously pointed out that 'decades of hard work have left their mark on those who farm for a living' (p. 90) and therefore keeping up activities on the farm in old age and remaining embedded in the farming community serves to create meaning, value and purpose in their lives (ibid). As the accumulation of symbolic capital necessitates 'considerable labour and time devoted to making and maintaining relations and to material and symbolic investments'. (Fuchs, 2003, P.392) a major complicating factor for older farmers faced with the prospect of transferring the family farm, relinquishing control and retiring, may therefore be the fear that their lifetime accrual of symbolic capital practically evaporates overnight, leading to a sense of insignificance and a lack of purpose. 
Burton (2004) and Burton et al. (2008) refer to a number of studies showing that farmers resist change that requires giving up their socio-cultural status acquired through productivist agricultural roles. Family business literature points out that 'many leaders need the admiration of their subordinates to feel truly alive. They crave an endless supply of narcissistic stimuli' and the 'prospect of climbing down off the top of the heap and becoming a nobody holds little attraction for them' (Kets de Vries, 2003, p. 708).

\subsection{Difficulty Relinquishing Control}

In addition to an anticipated loss of identity and status, results from the empirical research indicate that the senior generation of farmers may resist succession and retirement planning as a means of sustaining their positional dominance as head of the family farm. Surprisingly, $71 \%$ of respondents who had not considered retiring from farming in the future have in fact identified a potential successor to their farm somewhat contradicting the fact that $60 \%$ of these very farmers felt that the younger generation had the required experience, knowledge and skills to take over from them. Problem-Centred interviews identified that the idea of relinquishing control of the farm was not popular amongst many participants, in fact some went so far as to say that they would experience great difficulty in doing so, even if it was to their own children (see Barclay et al. 2012; Price and Conn, 2012; Whitehead et al., 2012). For example, mixed livestock farmer Aoife from the Midlands of Ireland, who is in an unofficial farm partnership with her son, explains:

'No I won't retire, because if I did I think I would literally go to the coffin, I would go to the graveyard. What I am saying is I wouldn't have any interest in anything else. My days are defined by farming.... Because that's what I am, that's who I am, that's what I do.... There is no way I would give up what I have, not even to the next generation, no It would be inevitable if I had to do it, I mean it wouldn't come naturally, it would be something that would be put upon me, it would be sickness or something, it would have to be a life changing ordeal or something or another'

Similarly, beef farmer David from the North West has great difficultly transferring over the family farm to his son:

'I have a son who is 30 this year and he wants to settle down and farm here and I suppose in a sensible ideal world I should transfer over the farm to him and my wife and I should buy a house in the local village or somewhere else and let him move in here. Well that would be in a sensible world, 
but I wouldn't even consider or suggest that. I am certainly not prepared to let go of what I have just yet'.

The concept of symbolic capital is critical to our understanding of how patterns of power and domination are reproduced in family farms and family firms. Crucially, symbolic capital forms a kind of institutionally organized and, to some extent, guaranteed source of recognition and prestige that incorporates power as an inherent feature of one's social position within a social arena (field) (Bourdieu 1977). An incumbent's formidable store of symbolic capital derived from being the primary operator of the business is thus an important aspect of their life as it defines their position and reputation within their family and indeed in society. Price and Conn (2012) also highlight that being the 'boss farmer' provides a certain status in a rural location. Therefore, the potential depletion of symbolic capital that may occur as a result of handing over full responsibility of the farm to the next generation and retiring may be difficult to absorb for many older farmers, because not only do they revel in the recognition, belief, esteem and confidence of others afforded to them via the possession of symbolic capital, but also the ability and power to impose their vision on the farm. Results from the research identify that $60 \%$ of farmers who have not considered retiring from farming agree with the suggestion that they would no longer be seen as having a leading role in their household and local community if they relinquished control and retired. Problem-Centred interviews confirmed that such a prospect places significant emotional stress on many participants. Tillage farmer Josh from the South East explains:

'Well I think history would tend to prove that that is the case. I know a lot of cases where farmer's have hung on and not transferred over but the minute they handed it over then their relationship and role suddenly changed within the family and that is a danger. Retirement changes the relationship with other farmers too, it certainly does and that is also a worrying factor'.

These findings again confirm the premise put forward by Lansberg (1988), that the fear of losing authority and governance of the firm by passing on the reins to the next generation is exacerbated by the perception that 'retiring from the firm will lead to a demotion from one's central role within the family' (p. 124). Similarly from a family farming perspective, Pitts et al. (2009) previously pointed out that the 'senior generation might be reluctant to engage in succession planning, as surrendering control of the farm relegates them to a more peripheral role' (p.61) and therefore, inevitably their ability and power to control and shape the events around them. 


\section{Conclusion}

The findings of this study provide a nuanced understanding of the complex and competing emotions currently derailing and deterring intergenerational family farm transfer. As the average age of the farming population is increasing worldwide, this investigation comes in a very timely manner. This research makes an exciting contribution by unpacking the relevance of applying family firm literature when investigating the psychodynamic and sociodynamic factors that influence the process of transferring the family farm business from the perspective of the senior generation. An abundance of family business literature exists on the resistance towards the process from the perspective of the incumbent, whereas its counterpart from a family farming perspective is largely absent. Connecting these previously disparate literatures, allowed us insight into the views of elderly farmers, their concerns, fears, needs and future plans. In advancing the theoretical construct, this paper identified the value of Bourdieu's notion of symbolic capital in comprehending the human factors governing the behaviour patterns and attitudes of elderly farmers facing succession and retirement. Using this concept, with associated characteristics of honour, prestige, position and status, contributes to a more discerning picture of the role emotional ties to the farm and farming occupation play on the decision-making process of the older farmer.

The prominent themes that emerged from the triangulation of empirical data, provide an appreciation of the complex nature of succession and retirement, while also reinforcing the condition that policy is 'underestimating the importance of symbolic capital' when discussing the issue of intergenerational family farm transfer. Transferring the family farm returns little symbolic capital to older farmers. Many farmers' identity and self-esteem are strongly attributed to their occupation and as a result sacrificing one's professional and personal identity upon transferring managerial control of the farm and retiring is a concept that they find difficult to accept. Our research finds that farmers resist transferring the farm on the basis of an anticipated loss of the recognition and social status that has accompanied their position as an active and productive farmer in society. Subsequently the senior generation resist succession and retirement planning as a means of sustaining their position as head of the family farm. As an older farmer's symbolic capital appears to be founded not only on their past achievements but also on present production, the thought of being 'retired' is found to be particularly arduous for them. Consequently even the most sophisticated of family farm transfer plans are of little avail if policy makers and practitioners are not adequately cognizant and understanding of 'the language of farming' (Burton, 2004, p. 212) and how painful it is for the older generation of farmers to 'let go'. 
Empirical findings brought focus on the suitability of farm transfer policy strategies such as Early Retirement Schemes put in place in the Republic of Ireland over the past four decades. These schemes, we argue, had little or no regard for older farmer's emotions and were excessively preoccupied with financial incentives to encourage the process. While such economic efforts to confront the issue are important and indeed have been in many aspects well meaning, empirical findings here have identified many more facets to the farm transfer decision-making process, which in large part have been neglected. The outcome; a derailment of the process in many cases. For example, the eligibility requirements for farmers entering the most recent Early Retirement Scheme for farmers (ERS 3) (June, 2007), was that 'Persons intending to retire under the Scheme shall cease agricultural activity forever'. Essentially, farmers were being asked to revise their selfperceptions upon retirement. This largely unsuccessful scheme (it was suspended in October, 2008) was completely oblivious to the mind-set of many farmers as exemplified here. Being recognised as an active and productive farmer in society has been acknowledged as being central to a farmer's sense of self. As symbolic capital is situational, the symbolic capital assigned to a person in one situation may not necessarily carry over into other situations. Thus the prospect of going from being an active and productive farmer to permanently ceasing all farming activity upon retirement as demanded in this retirement scheme, forces older farmers to face a number of what could be termed, painful realities. Realities that come with the consciousness of letting go of one's professional identity, becoming a retiree and becoming more and more dependent on others. The resultant outcome leads farmers, in many cases to resist the process.

In an era of unprecedented transition in global agriculture, we acknowledge that the global phenomenon of an aging farming population calls for and justifies the development of various incentives to stimulate and entice family farm transfer. This will enable enthusiastic young farmers gain access to productive assets and subsequently improve the competitiveness of the agricultural sector. One such policy is the farm partnership model, where two or more partners operate their enterprises jointly. This model can be seen as a stepping stone to farm transfer, however, similar to the sporadic uptake of previous Early Retirement Schemes, the low number of farm partnerships currently in operation in the Republic of Ireland indicates that policies and supports need to be amended in order to encourage greater participation. In an attempt to spur on the process, the Department of Agriculture, Food and the Marine launched a collaborative farming scheme in 2015, funded under Ireland's Rural Development Programme and co-funded by the European Agricultural Fund for Rural Development (EAFRD), to 'encourage the establishment of new farm partnership arrangements by contributing to the legal, advisory and financial services costs incurred by farmers in the drawing up of their farm partnership agreement' (DAFM, 2015). While this is still very new, what is interesting here however is that this scheme has again a simplified view of the factors influencing the process and fails to deal with the complex emotional dynamics facing ageing 
Conway et al., 2016. Cease Agricultural Activity Forever? Underestimating the Importance of Symbolic Capital, Journal of Rura I Studies, 44: 164-176 farmers identified in this research. Findings of this study illustrate that in many cases, the older generation, through their own admission, prioritize the building and maintenance of their personal possession of symbolic capital rather than transferring the family farm and retiring. Therefore, echoing calls made by Commins (1973), we argue that any new initiatives put in place to support and encourage intergenerational family farm transfer should not be conceived so narrowly as to ignore possible social consequences or wider issues of human dignity. Both social and economic needs must be catered to, and ideally a policy for structural reform in agriculture must be accompanied by a comprehensive set of interventions to deal with the personal and social loss an older farmer may experience upon transferring the family farm.

In order to do this, we advocate that future policies and programmes relating to family farm transfer take into account the pervasiveness of symbolic capital and work within this structure to effect change. For example, on its own, and with the numerous perceived negative connotations associated with it identified, we suggest that the term 'Early Retirement Scheme' is no longer appropriate for policy to use in a farming context. Perhaps the term 'Farm Progression Scheme' would be more effective as it portrays a sense of purposefulness rather than one of cessation to an elderly farmer. In addition, instead of reporting that farm management decisions are in the hands of a generation who may be more resistant to structural change and growth, policy makers and key stakeholders need to embrace, publically promote and recognise the older generation's invaluable store of knowledge, skills and years of experience working on the farm that the younger generation have not yet accumulated. The feeling of still being valued and needed in society may reinforce the older farmers' morale and sense of purpose in the face of the gradual diminishment of their physical capacities. This may help to diminish the stigma and defeatist stereotype associated with transferring the family farm and subsequently promote a more positive and wilful attitude towards the process over time. The development of such strategies concerning the human dynamics of family farm transfer has the potential to greatly ease the stresses of the process. Anyone who considers such recommendations to be too idealistic, should remember that we all inevitably have to face the prospect of letting go of our professional tasks and ties in our old age. No one can avoid aging and as this research has identified, most elderly farmers opt to maintain the facade of normal day to day activity and behaviour instead of retiring. As such, this paper, in attempting to understand the world as farmers perceive it, can be drawn upon to inform future policy directions and as a consequence prevent older farmers from being isolated and excluded from society almost by accident rather than intention. This research is but a start however and the insights given and issues raised will hopefully stimulate further investigations along these lines. In future work, it would be valuable to further explore the power dynamics within family farm households identified in this research. As the older farmer often has accumulated a great deal of symbolic capital throughout their lifetime, a question that warrants additional investigation is the degree to which they exploit their symbolic power as head of the household and farm in their struggle with the younger generation for control and ownership of the family farm. 


\section{Acknowledgements}

We are grateful to all the farmers who took part in this research. Funding for this project was provided by the National University of Ireland, Galway's College of Arts, Social Sciences, and Celtic Studies Galway Doctoral Research Scholarship Scheme and the Geographical Society of Ireland postgraduate travel award bursary. We would also like to thank Teagasc, the agriculture and food development authority in Ireland, for their assistance with this research.

\section{Bibliography}

ADAS (Agricultural Development and Advisory Service), 2004. Entry to and Exit from Farming in the United Kingdom (RMP 2037). Report prepared for: The Department for Environment, Food and Rural Affairs

ADAS (Agricultural Development and Advisory Service), 2007. Study of joint venture farming, Defra, London

Ajzen, I., 1991. The theory of planned behaviour, Organizational Behaviour and Human Decision Processes, 50, 179-211

Babbie E. and Mouton, J. 2001. The practice of social research, Cape Town: Oxford University Press.

Baker, J., 2012. So What? Pp. 129-148 in M. Lobley, J. Baker and I. Whitehead eds, Keeping it in the family: international perspectives on succession and retirement on family farms (Ashgate)

Barclay. E., Reeve, I. and Foskey, R., 2012. Australian Farmers' Attitudes Towards Succession and Inheritance Pp. 21-36 in M. Lobley, J. Baker and I. Whitehead eds, Keeping it in the family: international perspectives on succession and retirement on family farms (Ashgate)

Bernstein, D.A., Penner, L.A., Clarke-Stewart, A. and Roy, E.J., 2006. Psychology, Sixth Edition, Houghton Mifflin Company

Bika, Z., 2007. The Territorial Impact of the Farmers' Early Retirement Scheme, Sociologia Ruralis $47(3), 246-272$

Bogue, P., 2013. Land mobility and succession in Ireland, Research report commissioned by Macra na Feírme in partnership with the Irish Farmers Association, The Agricultural Trust and the Department of Agriculture, Food and the Marine.

Borthwick, A. M., Boyce, R. A. and Nancarrow, S. A., 2015. Symbolic power and professional titles: the case of 'podiatric surgeon', Health Sociology Review 
Conway et al., 2016. Cease Agricultural Activity Forever? Underestimating the Importance of Symbolic Capital, Journal of Rura I Studies, $44: 164-176$ Bourdieu, P., 1977. Outline of a theory of practice (R. Nice, Trans.). Cambridge, England: Cambridge

University Press

Bourdieu, P., 1984. Distinction: A social critique of the judgment of taste (R. Nice, Trans.). Cambridge, MA: Harvard University Press

Bourdieu, P., 1985. The social space and the genesis of groups, Theory and Society, 14 (6), $723-744$ Bourdieu, P., 1986. The forms of capital. In J. G. Richardson (Ed.), Handbook of theory and research for the sociology of education (pp. 241-258). New York, NY: Greenwood

Bourdieu, P. 1990. In other words. Cambridge: Polity Press.

Bourdieu, P. and Wacquant, L.J.D., 1992. An Invitation to Reflexive Sociology, Cambridge, Polity Press Brockhaus, R. H., 2004. Family Business Succession: Suggestions for future research. Family Business Review, 17(3), 165-177

Burton, R. J. F., 2004. Seeing through the 'good farmer's' eyes: towards developing an understanding of the social symbolic value of 'productivist' behaviour, Sociologia Ruralis, 44 (2), 195-215.

Burton, R. and Walford, N., 2005. Multiple succession and land division on family farms in the South East of England: A counterbalance to agricultural concentration? Journal of Rural Studies, 21(3),

\section{$335-347$}

Burton, R.J.F., Kuczera, C. and Schwarz, G., 2008. Exploring Farmers' Cultural Resistance to Voluntary Agri-Environmental Schemes, Sociolgia Ruralis, 48 (1), 16-37

Calus, M., Van Huylenbroeck, G. and Van Lierde, D., 2008, The Relationship between Farm Succession and Farm Assets on Belgian Farms. Sociologia Ruralis, 48(1), 38-56

Central Statistics Office., 2012. Census of Agriculture 2010 - Final Results

Christian, B. and Bloome, D., 2004. Learning to Read Is Who You Are, Reading and Writing Quarterly 20(4), 365-84

Christensen, C. R., 1953. Management Succession in Small and Growing Enterprises, Boston:

Graduate School of Business Administration, Harvard University

Cohen, L., and Manion, L., 1986. Research methods in education, London: Croom Helm Commins, P., 1973. Retirement in agriculture: a pilot survey of farmers' reactions to E.E.C. pension schemes. Dublin: Macra na Feirme

Commins, P. and Kelleher, C., 1973. Farm Inheritance and Succession, Macra Na Fairme, Irish Farm Centre, Dublin, Ireland 
Conway et al., 2016. Cease Agricultural Activity Forever? Underestimating the Importance of Symbolic Capital, Journal of Rura I Studies, $44: 164-176$ Connolly, L., 2009. Global Agriculture 17th International Farm Management Congress, Bloomington/Normal, Illinois, USA Peer Review Paper Changing Structure and Production patterns of Irish Agriculture - Trends and Prospects

Convery, I., Bailey, C., Mort, M. and Baxter, J., 2005. Death in the wrong place? Emotional geographies of the UK 2001 foot and mouth disease epidemic, Journal of Rural Studies 21(1), 99-109

Creswell, J. W., 2005. Educational research: Planning, conducting, and evaluating quanitative and qualitative research. Upper Saddle River, NJ: Pearson Education, Inc.

DAFF (Department of Agriculture, Fisheries and Food), 2010. The Food Harvest 2020: A Vision for Irish Agri-food and Fisheries. Department of Agriculture, Fisheries and Food, Dublin, Ireland DAFM (Department of Agriculture, Food and the Marine), 2015. Coveney launches $€ 3 M$ grant scheme to support collaborative farming, 128/15 [press release]

Danco, L., 1982. Beyond Survival. Cleveland: The University Press

Defra (Department for Environment, Food \& Rural Affairs), 2002. Farming and food: a sustainable future, Report of the policy commission on the future of farming and food

De Massis, A. Chua, J. H. and Chrisman, J. J., 2008. Factors preventing intra-family succession, Family Business Review, 21(2), 183- 199

DGIP (Directorate-General for Internal Policies), 2012. EU Measures to Encourage and Support New Entrants, Policy Department B Structural and Cohesion Policies, Agriculture and Rural Development

Emirbayer, M. and Johnson, V., 2008. Bourdieu and organizational analysis, Theory and Society, 37(1), 1-44

Errington, A., 2002. Handing over the reins: A comparative study of intergenerational farm transfers in England, France and Canada', paper prepared for presentation at the Xth EAAE Congress, Exploring Diversity in the European Agri-Food System' Zaragoza (Spain) 28-31 August, 2002

Errington, A. and Lobley, M., 2002. Handing over the reins, A comparative study of international farm transfers. Paper presented to the Agricultural Economics Society Annual Conference

European Commission, 2013. Structure and dynamics of EU farms: changes, trends and policy relevance, EU Agricultural Economics Briefs, (9), October 2013

European Commission, 2015. EU farms and farmers in 2013: an update, EU Agricultural and Farm Economics Briefs, (9), November 2015

Field, J., 2003. Social capital, New York: Routledge

Formosa, M., 2007. A Bourdieusian interpretation of the University of the Third Age in Malta, Journal of Maltese Education Research, 4(2), 1-16

Forest, B. and Johnson, J., 2002. Unravelling the Threads of History: Soviet-Era Monuments and Post- 
Conway et al., 2016. Cease Agricultural Activity Forever? Underestimating the Importance of Symbolic Capital, Journal of Rura I Studies, 44: 164-176 Soviet National Identity in Moscow, Annals of the Association of American Geographers, 92 (3), 524547

Foskey, R., 2005. Older farmers and retirement: A report for the rural industries and development corporation, Kingston, ACT: RIRDC Publication No 05/006

Fuchs, C., 2003. Some implications of Pierre Bourdieu's works for a theory of social self-organization, European Journal of Social Theory 6 (4), 387-408

Gagnè, M., Wrosch, C. and Brun de Pontet, S., 2011. Retiring from the family business: The role of goal adjustment capacities, Family Business Review, 24, 292-304

Gasson, R. and Errington, A., 1993. The Farm Family Business, Wallingford, CAB-International Gee, S. and Baillie, J., 1999. Happily ever after? An exploration of retirement expectations, Educational Gerontology, 25(2), 109-128

Gillmor, D. A., 1977. Agriculture in the Republic of Ireland, Budapest: Akadémiai Kiadó.

Gillmor, D. A., 1999. The Scheme of Early Retirement from Farming in the Republic of Ireland, Irish Geography 32(2), 78-86

Glover, J.L., 2010. Capital Usage in Adverse Situations: Applying Bourdieu's Theory of Capital to Family Farm Businesses. Journal of Family and Economic Issues, 31 (4), 485-497

Glover, J.L., 2011. Resilient Family Firms in the Rural Landscape: The Role of Symbolic Capital. Conference Paper presented at the 34th ISBE conference Sheffield

Goeller, D., 2012. Facilitating Succession and Retirement in US Agriculture: The Case of Nebraska Pp. 149-164 in M. Lobley, J. Baker and I. Whitehead eds, Keeping it in the family: international perspectives on succession and retirement on family farms (Ashgate)

Handler, W. C., 1990. Succession in Family Firms: A Mutual Role Adjustment between Entrepreneur and Next-generation Family Members, Entrepreneurship: Theory and Practice, 15(1), 37-51

Handler, W. C., 1994. Succession in family business: a review of the research, Family Business Review, 7 (2), 133-57

Handler, W. C, and Kram, K. E., 1988. Succession in Family Firms: The Problem of Resistance. Family Business Review, 1(4), 361-381

Hennessy, T. C. and Rehman, T., 2007. An investigation into factors affecting the occupational choices of nominated farm heirs in Ireland, Journal of Agricultural Economics, 58(1), 61-75

Hofer, C.W. and Charan, R., 1984. The transition to professional management: Mission impossible? American Journal of Small Business, 9(1), 1-11

Holt, D., 1998. Does Cultural Capital Structure American Consumption? Journal of Consumer Research, 25 (1), 25-79 
Conway et al., 2016. Cease Agricultural Activity Forever? Underestimating the Importance of Symbolic Capital, Journal of Rura I Studies, 44: $164-176$ Ingram, J., and Kirwan, J., 2011. Matching new entrants and retiring farmers through farm joint ventures: insights from the Fresh Start Initiative in Cornwall, UK. Land Use Policy, 28(4), 917- 927

Irish Farmers Journal, 2012 - Agricultural Land Price Report 2011

Jenkins, R., 1992. Pierre Bourdieu, London: Routledge

Joppke, C., 1986. The cultural dimensions of class formation and class struggle: On the social theory of Pierre Bourdieu. Berkeley Journal of Sociology, 31, 53-78

Keating, N. C., 1996, Legacy, aging, and succession in farm families. Generations, 20(3), 61-64

Kelly, L. M., Athanassiou, N., and Crittenden, W. F., 2000. Founder centrality and strategic behaviour in the family-owned firm, Entrepreneurship Theory and Practice, 25(2), 27.42

Kets de Vries, M.F.R., 1985. The Dark Side of Entrepreneurship, Harvard Business Review, Nov-Dec., 63(6), 160-167

Kets de Vries, M. F.R., 2003. The Retirement Syndrome: The Psychology of Letting Go, European Management Journal, 21 (6), 707-716

Kimhi, A. and Lopez, R., 1997. Retirement Planning and Succession Considerations of Maryland Farmers, Evidence from a Household Survey, Paper presented at the 11th Annual Conference of the European Society for Population Economics

Kirkpatrick, J., 2012. Retired Farmer - An Elusive Concept Pp. 165-178 in M. Lobley, J. Baker and I. Whitehead eds, Keeping it in the family: international perspectives on succession and retirement on family farms (Ashgate)

Kirkpatrick, J., 2013. Retired Farmer - An Elusive Concept, Choices- The Magazine of Food, Farm, and Resource Issues, 2nd Quarter 2013

Lange, K. Y., Johnson, J.W., Hudson, D., Johnson, P.N. and Gustafson, B., 2011. Equal or Just? Intergenerational Allocations within Family Farm Businesses, Southern Agricultural Economics Association Annual Meeting, Corpus Christi, Texas

Lansberg, I., 1988. The Succession Conspiracy: Resistances to Succession Planning in First Generation Family Firms, Family Business Review, 1(2), 119-143

Lapple, D. and Hennessy, T., 2012. The capacity to expand milk production in Ireland following the removal of milk quotas, Irish Journal of Agricultural and Food Research 51, 1.11

Lobley, M., Johnson, G., Reed, M., Winter, M. and Little, J., 2004. Rural stress review final report. UK: Centre for Rural Research, University of Exeter

Lobley, M., Baker, J., R and Whitehead, I., 2010, Farm succession and retirement: Some international 
Conway et al., 2016. Cease Agricultural Activity Forever? Underestimating the Importance of Symbolic Capital, Journal of Rura I Studies, 44: $164-176$ comparisons. Journal of Agriculture, Food Systems, and Community Development, 1(1), 49-64

Lobley M., 2010. Succession in the Family Farm Business, The Oxford Farming Conference

Maton, K., 2008. Habitus. In M. Grenfell (Ed.), Pierre Bourdieu: key concepts (pp. 49-65). Durham: Acumen Publishing Limited

Mayring, P., 2000. Qualitative content analysis, Forum: Qualitative Social Research, 1(2)

Mesquita, B. and Boiger, M., 2014. Emotions in context: A sociodynamic model of emotions. Emotion Review, 6, 298-302

McLeod, M., 2012, Business Continuance and Succession Planning: A New Zealand Perspective. Pp. 179-192 in M. Lobley, J. Baker and I. Whitehead eds, Keeping it in the family: international perspectives on succession and retirement on family farms (Ashgate)

Meehan, A., 2012. Land for Dairying - New Legal and Tax Models in an Irish Context' Nuffield Scholarship Study 2012

Mishra, A.K. and El-Osta, H.S., 2007. Factors Affecting Succession Decisions in Family Farm Businesses: Evidence from a National Survey, Journal of the American Society of Farm Managers and Rural Appraisers, 70(1), 1-10

National Rural Network, 2011. NRN Case Study, Facilitating and Encouraging Older Farmers to Retire National Rural Network, 2013. NRN Case Study, Achieving Greater Land Mobility in Ireland NESC (National Economic and Social Council), 1997. New Farm Operators 1971 to 1975, National Economic and Social Council, Report No. 27. Dublin

Nicholls, G., 2005. The challenge of scholarship: rethinking learning, teaching and research. London: Routledge

Palliam, R, Cader, H, A and Chiemeke, C., 2011. Succession issues among family entrepreneurs in the countries of the Gulf, International Journal of Business Administration, 2(2)

Pitts, M.J., Fowler, C., Kaplan, M.S., Nussbaum, J. and Becker, J.C., 2009. Dialectical Tensions Underpinning Family Farm Succession Planning, Journal of Applied Communication Research, 37(1), 59-79

Pile, S., 1990. The Private Farmer - Transformation and Legitimating in Advanced Capitalist Agriculture. Dartmouth, Aldershot.

Potter, C. and Lobley, M., 1992. Ageing and succession on family farms: the impact on decision making and land use, Sociologia Ruralis, 32(2-3), 317-334 
Price, L. and R. Conn., 2012. 'Keeping the name on the land': patrilineal succession in Northern Irish family farming. Pp. 93-110 in M. Lobley, J. Baker and I. Whitehead eds, Keeping it in the family: international perspectives on succession and retirement on family farms (Ashgate)

Rogers, M., Barr, N., O'Callaghan, Z., Brumby, S. and Warburton, J., 2013. Healthy ageing: Farming into the twilight. Rural Society, Work and Environment, 22(3), 251-262

Rossier, R., 2012. Farm succession in Switzerland: From generation to generation, Pp. 75-91 in M. Lobley, J. Baker and I. Whitehead eds, Keeping it in the family: international perspectives on succession and retirement on family farms (Ashgate)

Ryan, M., 1995. Early Retirement for farmers: The OCED Observer, 194, 24

Scheibelhofer, E., 2005. A Reflection Upon Interpretive Research Techniques: The Problem-Centred Interview as a Method for Biographic Research' In: Narrative, Memory Everyday

Life. University of Huddersfield, 19-32

Sharma, P., Chrisman, J.J., Pablo, A.L., and Chua, J.H., 2001. Determinants of initial satisfaction with the succession process in family firms: A conceptual model. Entrepreneurship Theory and Practice, 25(3), 17-35

Sharma, P., Chrisman, J. J., and Chua, J. H., 2003. Succession planning as planned behaviour: Some empirical results. Family Business Review, 16(1), 1-15

Simms, D.G., 1988. Advising the Family Business Owner in Succession Planning: The Daughter Option, 36 Clev. St. L. Rev. 597

Swartz, D. L., 1997. Culture and Power: The Sociology of Pierre Bourdieu. Chicago, IL: University of Chicago Press

Swartz, D. L., 2013. Symbolic Power, Politics, and Intellectuals: The Political Sociology of Pierre Bourdieu, Chicago: University of Chicago Press

Teagasc, 2011. Agricultural Education: Supporting Economic Recovery, Teagasc, Dublin Castle February 2011

Uchiyama, T. and Whitehead, I., 2012. Intergenerational Farm Business Succession in Japan. Pp. 5573 in M. Lobley, J. Baker and I. Whitehead eds, Keeping it in the family: international perspectives on succession and retirement on family farms (Ashgate) 
Uchiyama T., Lobley M., Errington A. and Yanagimura S., 2008. Dimensions of intergenerational farm business transfers in Canada, England, the USA and Japan, Japanese Journal of Rural Economics, 10, 33-48

Üstüner, T., and Thompson, C. J., 2012. How Marketplace Performances Produce Interdependent Status Games and Contested Forms of Symbolic Capital. Journal of Consumer Research 38(5), 796814

Vare, M., 2006. Spousal effect and timing of retirement, Journal of Agricultural Economics 57(1), 6580

Ward, J. L., 1987. Keeping the Family Business Healthy: How to Plan for Continuing Growth, Profitability, and Family Leadership. San Francisco: Jossey-Bass.

Webb, J., Schirato, T. and Danaher, G. R., 2002. Understanding Bourdieu, Crows Nest, NSW: Allen \& Unwin

Whitehead, I., Lobley, M., and Baker, J., 2012. From generation to generation: drawing the threads together. Pp. 213-240 in M. Lobley, J. Baker and I. Whitehead eds, Keeping it in the family: international perspectives on succession and retirement on family farms (Ashgate)

Witzel, A., 2000. The Problem-Cantered Interview, Forum: Qualitative Social Research, 1(1), Art. 22

Zagata, L. and Lošilák, M., 2014. Farming Transitions: Pathways towards Regional Sustainability of Agriculture in Europe, WP4 Final Report

Zarei, E., and Pirnajmuddin, H., 2014. Self-Fashioning in Pope's Epistle to Dr. Arbuthnot: A Bourdieusian Reading, International Letters of Social and Humanistic Sciences, 40, 64-77 